Revue bibliographique pour le domaine irano-aryen

\title{
Henning Börm. „Barbaren als Tyrannen. Das Perserbild in der klassizistischen griechischen Historiographie“
}

Reinhardt Pirngruber

\section{(2) OpenEdition Journals}

Electronic version

URL: https://journals.openedition.org/abstractairanica/53436

DOI: 10.4000/abstractairanica.53436

ISSN: 1961-960X

Publisher:

CNRS (UMR 7528 Mondes iraniens et indiens), Éditions de l'IFRI

\section{Electronic reference}

Reinhardt Pirngruber, “Henning Börm. „Barbaren als Tyrannen. Das Perserbild in der klassizistischen griechischen Historiographie" ${ }^{u \prime \prime}$, Abstracta Iranica [Online], Volume 42-43| 2021, document 50, Online since 30 December 2021, connection on 13 December 2022. URL: http://journals.openedition.org/ abstractairanica/53436 ; DOI: https://doi.org/10.4000/abstractairanica.53436

This text was automatically generated on 13 December 2022 .

All rights reserved 


\title{
Henning Börm. „Barbaren als Tyrannen. Das Perserbild in der klassizistischen griechischen Historiographie“"
}

\author{
Reinhardt Pirngruber
}

\section{REFERENCES}

Henning Börm. „Barbaren als Tyrannen. Das Perserbild in der klassizistischen griechischen Historiographie“ in R. Rollinger, K. Ruffing, L. Thomas (eds.). Das Weltreich der Perser. Rezeption - Aneignung - Verargumentierung. Wiesbaden: Harrassowitz Verlag, 2019, p.15-34

H. Börm argues that the depiction of Sasanian emperors in Late Antique 'classicicst' historiography (Ammian, Procopius, etc.) was deeply influenced by the way Greek historians of the $5^{\text {th }}$ and $4^{\text {th }}$ centuries BCE wrote about the Achaemenid Great King. The representation of the latter in turn has to be understood in the context of Greek political, and usually anti-monarchical, discourse of the Classical period. Under the changed political framework of the later Roman Empire, the Sasanian emperors then provided a convenient template for more or less concealed criticism of the imperium Romanum. 


\section{AUTHORS}

\section{REINHARDT PIRNGRUBER}

Institut für Orientalistik, Wien 